\title{
NOSTALGIA AFTER THE COMMUNIST REGIME IN ROMANIA
}

\author{
Dan Teşculă \\ Faculty of History, Babeş-Bolyai University Cluj, \\ Strada Mihail Kogălniceanu 1, Cluj-Napoca, Romania \\ E-mail address: dantescula@gmail.com
}

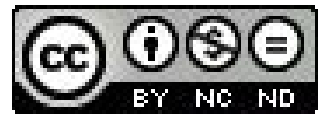

\begin{abstract}
The present paper focuses on the nostalgia after the communist regime in Romania. This small study is a general overview of the progress I have made during the period between march and august on my $\mathrm{PhD}$ thesis regarding the nostalgia after the communist regime in Romania. The research methodology used is somewhat new in the field of conteporary history research. The quasi-experimental study was used in order to see if there are significant differences in the way the well-defined social categories perceive the feeling of nostalgia after communism. The period we spanned in this study is the so-called Ceauşescu epoch for wich we have had the most material to work with. From a historiographycal stand-point, the subject is very new, up until now the studies that have appeared during the past years, take the form of articles published in scientific reviews. More studies will eventually show up in the years to come. During this study we have identified small differences between the groups, that posess almost no relevance to our hypothesis. Theoretically educated people know how to present their memories which later have served as an explanation as to why they are not nostalgic. Surprisingly the working class has almost the same perception as the educated people (the intellectuals).
\end{abstract}

Keywords: social memory, collective memory, victimization, communism, nostalgia

\section{INTRODUCTION}

Since the events of 1989, Romania has travelled a long and bumpy road seeded in places with big obstacles. One of these is an intense feeling of regret towards the past. Of course the past is a significant part of our lives in which each and every one of us is living his/her own biography and projecting its own future in a determined historical period, hence contributing to the society in which he/she has lived, but the past can also be a bourden that could be generated by the lack of adapting skills or mechanisms of an individual, or simply having a feeling of regret towards the past.

Still, we ask ourselves: what does it mean to be a nostalgic? All of the answers seem to have a positive connotation that when invoking the past, one tends to think about the positive sides of it. When a significant group of people is weeping over its totalitarian past in which the individuals have starved, and lacked the 
esentials for civilized life (eg. The limited electricity, the limited TV programmes, the lack of good quality clothing, etc.) forbidded by the state, we believe that a significant number of people have either an imprecise (or distorted) image of the past, produced by psychical rationally uncontrolled mechanisms, or maybe the original contemporary romanian society has no rules or coherence in its actions.

From a semantical point of view, the word nostalgia has a lot of meanings and definitiions. The term first appeared as a madical term used in the context of evoking a feeling of anxiety of the swiss mercenaries that fought far away from their homelands, hence the connotation of homesickness. The first to describe the feeling was Johannes Hofer in the work Dissertatio medica de Nostalgia sau Heimweche", edited in 1688 (Davies, 1979, p 18). The symptoms presented by the swiss scholar include high fever, the feeling of nausea, vomiting and in some cases, death. XVII ${ }^{\text {th }}$ cantury millitary medics have postulated the hypothesis that nostalgia was a disease that caused the deterioration of the brain cells of the victims. A century later scientists concluded that nostalgia is not a disease and that it must be seen as a symptom or a phase of a pathological process.

Of course, the word itself has different meanings: for instance, the germans (especially those who lived in the former DDR (Deutsche Demokratische Republik - Democratic German Republic) have used the term Ostalgie, to designate the redescovery of the memory in the eastern part of the country. Here we also have the term Ostagiker (Boyer, 1998, pp.361-380). A similar phenomenon can be noticed in the former Yugoslavia, the so-called Jugonostaljia. The Russians have used the word nostalgia to describe a deserted place or a deserted person that experiences a strong and idealized feeling of regret in regard to the glories past. Coming back to the ostalgie, we cannot go forward without mentioning the excellent work of Paul Cooke (Cooke, 2005) in wich we find a very interesting study about what the phenomena of the Ostalgie has represented for the TV and other mass-media sources of information.

\section{HISTORIOGRAPHY}

From a hystoriographic stand-point, the writings about the nostalgia after communism are only at the begining, starting from this centrury the important researches $\mathrm{n}$ this subject will make their presence felt in the cultural and scientific world, especially in the field of social life. In this little research we shall present in general the historiography of this period that is not only interesting but very controversial. The history of communism in general is very vast, much of the writings being printed in the West, giving birth to some of the most important works that nowadays became fundamental.

Tzvetan Todorov in the short but complete work The Abuses of Memory (Todorov, 1995) makes a competent analysis on the memory highlighting the component of evocation or rememoration, having a central point of interest in the necessity of evoking the past. He argues that the questions What and Why but also How are not relevant (but also useless) and that the fixation of the past must be 
done following a complex selection of information/data, a justified preparation of the information, as well as an orientation towards the future.

One of the memories that Todorov insists upon is the exemplary memory, described as a form of processing the information rationally and through analogies ranked from simple to complex, which helps to process and then fix the information in the collective mentality on a correct basis. Historians work does not necessarily consist in the establishment of the facts but also in the selection of some of them as being more relevant and significant than others in designating corelations between them. This kind of work to select and combining does not really have to be guided by the search for the truth, but by the good (Todorov, 1995, p. 9).

The Bulgarian professor also presents the memory of the past in democracy, that is seen as dangerous (if not more dangerous) than the memory from totalitarism. The overabundence of information the multitude of sources on a huge emotional background, takes the risk of talking to the same purpoes as in the totalitarian states, because the information is served already prepared hence the absence of a personal judgement on a personal level. In conclusion the stakes of the memory are much to important to be left captured by enthusiasm and anger.

A significant work on the study of a range of memories tied to nostalgia is Svetlana Boym's Nostalgia of the Future (Boym, 2001). In this study, nostalgia is seen as a sense of loss in a world caught between romanticized versions of the past in contrast with the dark and decadent present (Boym, 2001, p xiii).The author looked in detail at Khrushchev's Soviet regime, which is seen as the most future-oriented regime. For this reason, the idea of nostalgia disappears in intervening sacrifices to accede to a bright future. The author uses the argument that cosmic fascination embraced the Soviet Union after the space succeses of 1957-1963. The Ukrainian teacher undelines that in the debut of the $60 \mathrm{~s}$, the idealist-utopian promises made by the government and subsequently by other governments that the future generation must live in the glorious era of socialism in which people can travel to the moon (Boym, 2001, pp. 59-60).

An important study we find in Paul Cooke in his representations about German society and East Germany published in 2005 (Cooke, 2005). This study is basically a paper pertinently glancing at German society, especially towards the East Germans. In this work the author presents the West German perspective on their neighbors in the East, the GDR is tacitly recognized as an artificial state unfairly created by the Soviets. The last part of the study (the chapter Re-exorcising the normal German television and the Ostalgie industry) draws our attention because it deals with the feeling of nostalgia for the former East Germany, especially from the perspective of the GDR neighbours (Cooke, 2005, pp. 141-157). Cooke shows that interest in daily life in the former GDR appears somewhere in 2003 with the release of the film Good Bye, Lenin! In it, are clearly seen scenes of daily life in the east-german population. Basically the film served as a stimulus generator of nostalgia. It bears the name of nostagie or short für den Ost Ostalgie. German television (eg ZDF) will seize this Ostalgie, transforming it into a veritable media industry through programs like Ostalgie Show, in which stories about life in the former GDR occupied the main role. 
In Romania, studies regarding the nostalgia after the communist regime, up until 2004 were very few and far between. The studies regarding the every day life during that period, were studied on a number of occasions by western researchers like Kathrine Verdery, Dennis Deletant or David Kideckel (who we quoted earlier).

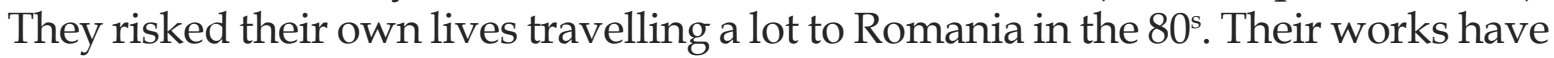
been published in their own countries in the mid $90^{\mathrm{s}}$ and later on the works were translated in Romanian. In the spring of 2004 a volume of studies coordinated by the late professor Adrian Neculau appeared in Iaşi with the title Every-day life of the Romanians in Communism (Neculau, 2004). In this volume we find studies from psychologists such as Aurora Liiceanu or other universitary professors or scholars like Andrei Cosmovici. The themes approached vary from the creation of a new national identity after 1945 (Neculau, 2004, p. 11) all the way to the famous queues formed in front of magazine or grocery stores (Cernat, 2004, pp. 47-58). Studies regarding the romaninan working class can be easily found in David A. Kideckel's studies materialized in a very interesting work (Kideckel, 2010). His results led him to the conclusion that the working class has suffered a lot from the collapse of communism, most of them being unemployed after their factories were shut down by the new government. For the condition of the intellectuals we found a volume of studies coordinated by Vladimir Tismăneanu and Sorin Antohi that follow the intellectual from the beginig of the regime all the way to the $21^{\text {st }}$ century (Antohi, Tismăneanu coord, 2005). The main conclusion of the volume has been summed up by Tismăneanu who quotes a former Solidarnosc activist -Bogdan Borusewicz- : when communism collapsed I really thaught that the best people will come in front and lead honestly and good. It was shown that people are people and the mishaps for wich we blamed the system are in fact written in all of us including myself (Tismăneanu, 2005, p. 244).

What is nostalgia in psychological terms? What does it mean to be nostalgic? Most answers to this question have their center in a positive connotation and good experiences that people relive defining the feeling nostalgic. Nostalgic memories are happy memories. Given this, it appears negative state - bad mood - a person or group of persons, as a positive state turns good in a state with a negative connotation?

The nostalgia state in these circumstances as explained above, is a complex feeling, an emotion, caused by a wrong projection of an event, and most often occurs as a reaction to a confused and misunderstood perception. From the outset it must be stressed that the individual retrieval system works on three components - encoding, storing, updating - the collective memory does not have a similar device (Schacter, 1987, p. 516). The collective memory does not settle past experiences in a cumulative way and requires continuous intervention in the past and transmission of knowledge about it is only on the information that is shared collectively (Safer, Levine, \& Drapalski, 2004, pp. 1498). Then: How does the collective memory operate if the group does not have a central processor as the brain for individual memory, that preserved it?

We propose a research paper by an interdisciplinary approach - history, social psychology, semantics - to analyze this construct in terms of collective memory in post-revolutionary Romania.

The design of the research methodology: premises, objectives, assumptions, methods, tools 


\section{PREREQUISITES FOR RESEARCH:}

Several reasons were the basis of the present research, which led design approach. Here they are:

1. Until this moment, we find insufficient scientific research results in controllable terms expressing the feelings of nostalgia regarding the communist regime. The researches, which are rather scarce are often expressed in the form of polls. It should be emphasized without contesting their value, because polls have basic demographics - age, occupation, gender, etc. - may not be validated as research - are not experimentally or by using several groups subjects to perform comparisons of different variables.

2. We propose a research paper by an interdisciplinary approach - history, social psychology, semantics - to analyze this construct in terms of collective memory in post-revolutionary Romania, quantitatively, to certify this social phenomenon, not axiological neutrality only but especially to be validated in terms of historical truth. The report history - memory must be done not only through the creation of museums but also scientific works.

3. The operationalization of the concept of nostalgia will be analyzed in particular by mainstream argument / argument - semantic; reasoning, fairness, errors reasoning, comparing arguments, finding a weak point argument - emotional; and socially, both personally and collectively.

4. Another argument in choosing the design theme is that research in the experimental method, is still in its infancy in historical research, we believe that the surest way is to verify the impact on the level of interest in the population and strengthen scientific research. Having well-defined groups whose test results can be compared to the results between the group members and between experimental groups are two advantages of experimental research that led to its choice to present research.

\section{OBJECTIVES AND ASSUMPTIONS:}

The hypothesis from which we started the research was that the majority of Romanians suffer from nostalgia for a repressive regime indefinitely considered. Idealization lived in this event in the past, makes living to receive new attributes, especially the restructuring of the memory and reinterpretation of each person.

- Scientific hypothesis - Hs - There are significant differences between the groups studied both in terms of nostalgic feelings, emotionally and in terms of fixing the collective memory of the communist past.

- The null hypothesis-Ho-: No significant differences between the groups studied

- Objective 1 - intellectual class nostalgia Study; Comparing constructs that define nostalgia among group members.

- Objective 2 - Study of the working class nostalgia; Comparing constructs that define nostalgia among group members.

- Objective 3 - Study nostalgia peasant class; Comparing constructs that define nostalgia among group members. 
- Objective 4 - Students study class nostalgia; Comparing constructs that define nostalgia among group members

- Objective 5 - Comparative studies between research groups taken

- Strategies: The study will be conducted on five groups - social categories mentioned above. Each group is composed of 30 respondents, randomly selected from the population at the time of the research. Eligible subjects are trained and are asked to express their written consent to participate in research. Filling scale tests of interview has no time limit, and is subject to confidentiality.

After tightening, test scoring and interpretation of qualitative evidence we will move to statistical analysis using SPSS programme.

\section{RESEARCH METHOD}

The method chosen to test hypotheses is quasi - experimental (Manipulations are not made by the researcher).

In a quasi-experimental design, the experimenter does not have the same control variables as in the experimental design. Quasi-Experiments independent variables and the dependent variables, but do not use random assignment of participants by level of the independent variable (the experimental group) in the quasi-experiment, compare non-equivalent groups

Due to the fact that it is not possible to control all or at least most of the variables involved, the design of research is quasi - experimental. Also, predetermined groups of subjects are randomly distributed, making this still be a variable that we can not control, plus other issues. Subjects were selected randomly, but through volunteering, we can assume that those who have registered an interest in the experimental group could positively influence the results. We can not control what happens outside the actual experimental amendment (it is disadvantageous design feature of quasi - experimental laboratory to experiment).

We propose a holistic model of evaluation of nostalgia. The instrument consists of a grid of 30 items of the interview the subject is required to select, on a scale of five, the most appropriate level of the person matches.

The design of the quasi - experiment used in this research is multifactorial, independent variables - classifiers - the social groups studied: intellectuals, workers, peasants, students and pupils.

Variables used in research:

- Independent classifiers (imposed by the researcher)

- Intellectuals, workers, peasants, students, pupils;

- dependence (subject aimed at behavior)

- Status of interviewees in terms of personal beliefs about our communist past; Items 1-6

- Status of nostalgic feelings interviewee economically. Items 7-12

- Memory communism - fixing the collective memory of the correct data Items 13-16 
- Status of interviewees emotionally as emotional distress, nostalgic; Items 17 to 22;

- Status of interviewees in terms of social micro and macro; Personal status optimism and hopes for the future Items 23 to 30 .

Tools used:

- Grid structured interview (Annex .1) - is used when the same questions are addressed to all study participants, and allow comparison of results (give a reduced flexibility and variation $\mathrm{R}$ ). Interview questionnaire is based on the assumption that:

1. Questions shall be such that they have the same meaning for all participants;

2. Interaction created in the study does not generate differences in the quality of data collection.

Advantage: interview grid - manageable, efficient, easy-coded and analyzed, allowing control of the interview.

Disadvantage: Difficulty of interview grid in building pertinent questions, the researcher is limited to the set of questions.

We have built an interview grid consisting in a total of 30 items, divided into five levels:

- Status of interviewees in terms of personal beliefs about our communist past. Items 1-6

- Status of nostalgic feelings interviewee economically. Items 7-12

- Memory communism - fixing the collective memory of the correct data. Items 13-16

- Status of interviewees emotionally as emotional distress, nostalgic. Items 17 to 22;

- Status of interviewees in terms of micro and macro social, personal status optimism and hopes for the future. Items 23 to 30

Likert scale marks, expressing agreement from 1 to 5.

Study participants:

Participants in the study were volunteers recruited from Cluj County, selected randomly.

Each participant was instructed about playing studio aiming interview grid and how to fill it, finally signed an agreement to participate and certainty of confidentiality.

Inclusion criteria:

- To qualify for Research (intellectuals, students, etc.)

- Aged 18 to 65

- Allow participation in the trial.

Exclusion criteria:

- Those who are not counted in the study încarează and that age does not correspond., Failure to assess the presence or absence of symptoms

- Diagnosed disease syndrome (mental illness, cancer, drug consumption, amphetamine) 


\section{DATA ANALYSIS METHODS USED}

The methods to be used to analyze the data are mixed. On the one hand we will use qualitative methods to get categorical data - but also common (quantitative). On the other hand frequencies for each group of items on the qualitative assessment will be used in statistical quantitative analysis.

The interview is usually a qualitative research method. When structured or semistructured it allows inclusion into categories and the setting of frequency for each symptom.

Fidelity qualitative analysis in this study is given by correlating data.

For quantitative analysis of the data will be applied repeatedly Chi square test $\left(\chi^{2}\right)$ to compare between different groups, bi-factorial analysis of variance (two-way ANOVA) between different groups, and will calculate the correlation coefficients biseriali for studying the relationship, the association between each variable and each study group continued.

We started the research by analyzing descriptive indicators: indices central tendency - mean, median and mode - and the variability - dispersion and standard deviation, for the first and second group studied - Lot Intellectuals - and Lot Workers constructs we analyzed groups but item by item status and aimed at personal beliefs about our communist past.

Because significant research statistically a sample depends on the sample size $(\mathrm{N})$, and the variability of the population from which the sample was drawn, we applied several statistical tests. The bigger the sample is more representative media and so the study is statistically confirmed.

I used the Mann-Whitney U - independent samples that supposedly considered the dependent variable was measured on an ordinal scale (rank order). Interpretation of the interpretation is essentially identical to the result of a T-test for independent samples, except that U-test ranking is based on the amounts. U-test is the most powerful (or sensitive) non-parametric alternative to the T-test for independent samples; In fact, in some cases, can provide greater power to reject the null hypothesis than the T-test. The second test used was Wilcoxon test, which is also non-parametric bivariate. We used to identify statistical differences semnificatieie identified or measured variables of respondents measurements using ordinal scales, regardless of the type of distribution. To establish the proportion observed in the study sample relative to the population use Z-test.

In the tables in Appendix 2 we see the results of the studied group types with each other, comparing example -I group of intellectuals with workers, intellectuals with students, intellectuals with students. Then I took the second lot and proceeded to successive analysis: student workers, workers with students etc; at the end, we analyzed in terms of the distribution backgrounds: Urban and Rural. Male and Female

Reporting is done with a significant threshold $-\mathrm{p}=0.05-$, which will involve the likelihood that our media should be within the range of $95 \%$ :

Because distribution is non-normal values in all groups, we discovered that the median is the 50th percentile and 25 percentile and 75 (see Appendix 2.Table 1.2. 
Show positioning within this range. For example: the score 1-6 intellectuals items it was $15(12 ; 19)$ and in 15 workers $(10.75 ; 18.25)$.

We compared the two groups (each with each, see Appendix 3) regarding score items. In the tables above, we will see if differences between groups are statistically significant. If $p<0.05$ when significant differences between groups. If $p>0.05$, then the differences are insignificant.

Ranks table provides summary information about the two variables volume groups, the average rank and rank sum test.

Test table includes values for Mann-Whitney test simultan.Valorile two variables of interest are those of table $Z$ and the level of confidence $p$. In our case it is noted that Total $1-6-Z=2.3$, the value of .48956 at a significance threshold of 0.01

\section{RESULTS}

Through the aforementioned methodology, taking and analyzing each lot we can identify how and to what extent is this feeling of nostalgia for the communist regime. So in a lot of intellectuals, students, peasants and workers, we made a comparative analysis of the results obtained from questionnaires.

In terms of personal beliefs about our communist past, the belief that a better life, regretted in the past regime. At first sight, we can say that there are marked differences between categories taken in research. Intellectuals, workers and students but even develop feelings of regret and share the opinion that the communist regime had a permissive ideology, social differentiation is bearable. The only plot Students show they have no significant experiences of this period. Noteworthy is that almost everyone thinks that the communist regime must be condemned, less vehement the students, which shows that they accept the past as something natural, without developing extreme experiences. They have an image of communism drawn from their parents stories and from the books they read. Status of interviewees nostalgic feelings of economic, social groups with strong beliefs note that the previous regime was better they are workers marks the highest score, while most oppressed sections of society are intellectuals and students.

Regarding the memory of communism - determining the correct data in the collective memory and their evocation of the communist past and reproduced more secure workers and intellectuals, while in sample students, the research area indicates that we do with a phenomena that I call communism as distant memory. We believe that for students, communism appears as an event in the distant past that will most likey never happened. The image of this regime is brought to them by the closest members of his family (parents, grandparents, uncles, etc.) or students recounted their memories. Status of interviewees emotionally as emotional distress, nostalgic students are developing the most researched categories stink emotional distress.

Status of interviewees in terms of micro and macro social, personal status optimism and hopes for the future show a comprehensive self-evaluation at a 
level low enough to average between 27 to 30 , which shows that value judgments about their own their person and optimism are relatively low.

Through the methodology set we can confirm or conversely, research refuted the hypothesis that such a study would start, especially the restructuring of the memory and reinterpretation of each person.

\section{REFERENCES}

Sorin, A., \& Tismăneanu, V. (2005). De la utopie la istorie [From Utopia to History]. Bucharest: Curtea Veche.

Boym, S. (2001). The Future of Nostalgia. New York: Basic Books.

Boyer D. (1998). Ostalgie şi Politica de viitor, în Germania de Est [Ostalgie and the Policy of the Future]. Cultura publică [Public Culture], 1. 361-381.

Cooke, P. (2005). Representing East Germany Since unification, from civilization to nostalgia. New York: Berg.

Davis, F. (1979). Desire for Yesterday; A Sociology on Nostalgia. New York: Free Press.

Kideckel, D. A. (2010). România postsocialistă [Post-socialist Romania], Bucharest: Humanitas.

Safer, M. A., Levine, L. J. \& Drapalski, A. L. (2004). Distorsion in memory for emotions: Thecontributions of personality and post-event knowledge. Personality and Social Psychology Bulletin, 28., pp 1495-1507.

Schacter, D. L. (1987). Implicit memory: History and current status. Journal of Experimental Psychology: Learning, Memory, and Cognition, 12. pp 501-518.

Todorov, T. (1999). Abuzurile memoriei [The Abuses of Memory], Timişoara: Armacord. 


\section{APENDIX 1}

\section{MODEL OF THE QUESTIONAIRE USED FOR THIS STUDY INERVIEW GRID INTERVIEW SCALE}

Initials .../..., Age........ Studies S, M, P, Place of Residence U, R,

Instructions: For every affirmation, please indicate in what mesure do you agree or disagree encircling the right number. Try to be as honest as posible and don $t$ let the answer to a question influence the other. There is no rght or wrng answers, we being only interested in your opinion.

Indicate how true is every affirmation for you. Encircle only one numberon each row.

\begin{tabular}{|c|c|c|c|c|c|}
\hline & 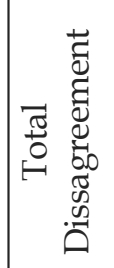 & 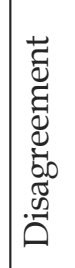 & 苞 & 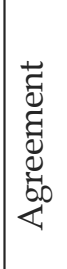 & 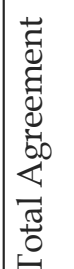 \\
\hline 1. In what mesure do you agree that before 1989 life was beter & 1 & 2 & 3 & 4 & 5 \\
\hline $\begin{array}{l}\text { 2. When you speak about communism do you rank that period } \\
\text { as being positive }\end{array}$ & 1 & 2 & 3 & 4 & 5 \\
\hline 3. The communist regime was good for the romanian people & 1 & 2 & 3 & 4 & 5 \\
\hline 4. Today you regret the fall of communism & 1 & 2 & 3 & 4 & 5 \\
\hline $\begin{array}{l}\text { 5. The communist regime had an unpermissive ideology that did } \\
\text { harm to the romanians }\end{array}$ & 1 & 2 & 3 & 4 & 5 \\
\hline $\begin{array}{l}\text { 6. You agree to the opinion that the social ranking in communism } \\
\text { was more subtle, hence more managable }\end{array}$ & 1 & 2 & 3 & 4 & 5 \\
\hline 7. Do you think that the communist regime should be condemned & 1 & 2 & 3 & 4 & 5 \\
\hline $\begin{array}{l}\text { 8. The political discourse after the fall of communism helped } \\
\text { installing democracy }\end{array}$ & 1 & 2 & 3 & 4 & 5 \\
\hline $\begin{array}{l}\text { 9. There is a posibility that the democracy installed in Romania } \\
\text { could be reversible }\end{array}$ & 1 & 2 & 3 & 4 & 5 \\
\hline $\begin{array}{l}\text { 10. Do you think that the dissapearence of the state-planned eco- } \\
\text { nomy led to the poverty we see nowadays }\end{array}$ & 1 & 2 & 3 & 4 & 5 \\
\hline 11. The low economical level is owed to the original leadership & 1 & 2 & 3 & 4 & 5 \\
\hline $\begin{array}{l}\text { 12. Lack of a coherent national projects makes the people look } \\
\text { for models in the past }\end{array}$ & 1 & 2 & 3 & 4 & 5 \\
\hline $\begin{array}{l}\text { 13.The current leaders use communist methods typical for the } \\
\text { state-planned economy }\end{array}$ & 1 & 2 & 3 & 4 & 5 \\
\hline $\begin{array}{l}\text { 14. Historians and analysts are not reporting correctly and objec- } \\
\text { tives of the communist period }\end{array}$ & 1 & 2 & 3 & 4 & 5 \\
\hline $\begin{array}{l}\text { 15. The meory of communism seems to be at the same time rele- } \\
\text { vant for the population which considers necessary the foun- } \\
\text { ding of a National Communist Dictatorship Museum. }\end{array}$ & 1 & 2 & 3 & 4 & 5 \\
\hline $\begin{array}{l}\begin{array}{l}\text { 16. When you remember the communist period do you feel sad, } \\
\text { melancholic (n.f) }\end{array} \\
\end{array}$ & 1 & 2 & 3 & 4 & 5 \\
\hline
\end{tabular}




\begin{tabular}{|c|c|c|c|c|c|}
\hline 17. In evereyday life you feel depressed, sad and lacking hope (n.df) & 1 & 2 & 3 & 4 & 5 \\
\hline $\begin{array}{l}\text { 18. When you think about your future you feel preocupied anxious or } \\
\text { stressed (n.f) }\end{array}$ & 1 & 2 & 3 & 4 & 5 \\
\hline $\begin{array}{l}\text { 19.You feel satisfied and optimistic regarding your future and that of } \\
\text { your (p e..) }\end{array}$ & 1 & 2 & 3 & 4 & 5 \\
\hline 20. I feel Ihave more freedom in personal decision making ( $p$ e.) & 1 & 2 & 3 & 4 & 5 \\
\hline $\begin{array}{l}\text { 21. I find it hard to fix my own goals and think about the future } \\
\text { as being safe. (n.df) }\end{array}$ & 1 & 2 & 3 & 4 & 5 \\
\hline $\begin{array}{l}\text { 22. Because of my condition it s hard for me to fulfill my responsabilities } \\
\text { that I have towards my family. (n.df) }\end{array}$ & 1 & 2 & 3 & 4 & 5 \\
\hline 22.I am happy with the quality of my life at present.( $p$ e..) & 1 & 2 & 3 & 4 & 5 \\
\hline 23. I m capable of doing things as good as everyone else (ss) & 1 & 2 & 3 & 4 & 5 \\
\hline 24. I consider myself valuable and the society needs me (ss) & 1 & 2 & 3 & 4 & 5 \\
\hline 25. I am generally satisfied with myself (ss) & 1 & 2 & 3 & 4 & 5 \\
\hline 26.I d wish more respect for myself (ss) & 1 & 2 & 3 & 4 & 5 \\
\hline 27.I have a positive atitude regarding my own persona (ss) & 1 & 2 & 3 & 4 & 5 \\
\hline $\begin{array}{l}\text { 28.I think we will never become a nation untill we respect each } \\
\text { other. (opt) }\end{array}$ & 1 & 2 & 3 & 4 & 5 \\
\hline $\begin{array}{l}\text { 29. I am worried that the future in my country will get worse } \\
\text { (opt) }\end{array}$ & 1 & 2 & 3 & 4 & 5 \\
\hline 30.I find the future grey (opt) & 1 & 2 & 3 & 4 & 5 \\
\hline
\end{tabular}


APPENDIX 2:

THE RESULTS SO FAR

Тв.1

\begin{tabular}{|c|c|c|c|c|c|c|c|c|c|c|}
\hline \multicolumn{10}{|l|}{ Percentiles } & \multirow[b]{3}{*}{95} \\
\hline & & \multirow[t]{2}{*}{ Lot } & \multicolumn{7}{|c|}{ Percentiles } & \\
\hline & & & 5 & 10 & 25 & 50 & 75 & 90 & 95 & \\
\hline \multirow{10}{*}{$\begin{array}{l}\text { Weighted } \\
\text { Average(Defini- } \\
\text { tion 1) }\end{array}$} & \multirow[t]{2}{*}{ Total1-6 } & intelectual & 6,00 & 8,00 & 12,00 & 15,00 & 19,00 & 21,00 & 25,00 & 25,00 \\
\hline & & workers & 7,10 & 8,00 & 10,75 & 14,00 & 18,25 & 20,00 & 22,35 & 22,35 \\
\hline & \multirow[t]{2}{*}{ Total 7-12 } & intelectual & 15,00 & 16,00 & 18,00 & 20,00 & 21,00 & 24,00 & 26,00 & 26,00 \\
\hline & & workers & 14,00 & 16,00 & 18,00 & 20,00 & 22,00 & 23,90 & 24,00 & 24,00 \\
\hline & \multirow[t]{2}{*}{ Total 13-15 } & intelectual & 8,50 & 9,00 & 9,00 & 10,00 & 12,00 & 13,00 & 13,00 & 13,00 \\
\hline & & workers & 6,55 & 7,10 & 9,00 & 10,00 & 11,00 & 11,90 & 12,45 & 12,45 \\
\hline & \multirow[t]{2}{*}{ Total 16-22 } & intelectual & 15,00 & 15,00 & 16,50 & 21,00 & 24,50 & 27,00 & 29,00 & 29,00 \\
\hline & & workers & 13,00 & 14,10 & 18,75 & 21,50 & 23,25 & 24,90 & 26,45 & 26,45 \\
\hline & \multirow[t]{2}{*}{ Total 23-30 } & \begin{tabular}{|l|} 
intelectual \\
\end{tabular} & 23,00 & 27,00 & 28,50 & 30,00 & 33,00 & 34,00 & 35,00 & 35,00 \\
\hline & & workers & 20,55 & 24,00 & 29,00 & 30,00 & 32,00 & 35,00 & 36,00 & 36,00 \\
\hline
\end{tabular}

TB. 2.

Ranks

\begin{tabular}{|c|c|c|c|c|}
\hline & Lot & $\mathrm{N}$ & Mean Rank & Sum of Ranks \\
\hline \multirow{3}{*}{ Total1-6 } & intelectuals & 29 & 31,57 & 915,50 \\
\hline & workers & 30 & 28,48 & 854,50 \\
\hline & Total & 59 & & \\
\hline \multirow{3}{*}{ Total 7-12 } & intelectuals & 29 & 29,48 & 855,00 \\
\hline & workers & 30 & 30,50 & 915,00 \\
\hline & Total & 59 & & \\
\hline \multirow{3}{*}{ Total 13-15 } & intelectuals & 29 & 33,48 & 971,00 \\
\hline & workers & 30 & 26,63 & 799,00 \\
\hline & Total & 59 & & \\
\hline \multirow{3}{*}{ Total 16-22 } & intelectuals & 29 & 30,47 & 883,50 \\
\hline & workers & 30 & 29,55 & 886,50 \\
\hline & Total & 59 & & \\
\hline \multirow{3}{*}{ Total 23-30 } & intelectuals & 29 & 30,90 & 896,00 \\
\hline & workers & 30 & 29,13 & 874,00 \\
\hline & Total & 59 & & \\
\hline
\end{tabular}

Test Statistics ${ }^{\mathrm{a}}$

\begin{tabular}{|l|l|l|l|l|l|}
\hline & Total1-6 & Total 7-12 & Total 13-15 & Total 16-22 & Total 23-30 \\
\hline Mann-Whitney U & 389,500 & 420,000 & 334,000 & 421,500 & 409,000 \\
Wilcoxon W & 854,500 & 855,000 & 799,000 & 886,500 & 874,000 \\
Z &,- 692 &,- 230 & $-1,570$ &,- 206 &,- 397 \\
Asymp. Sig. (2-tailed) &, 489 &, 818 &, 116 &, 837 &, 691 \\
\hline
\end{tabular}

a. Grouping Variable: Lot 


\begin{tabular}{|c|c|c|c|c|c|c|c|c|c|}
\hline & & \multirow[t]{2}{*}{ Lot } & \multicolumn{7}{|c|}{ Percentiles } \\
\hline & & & 5 & 10 & 25 & 50 & 75 & 90 & 95 \\
\hline \multirow{10}{*}{$\begin{array}{l}\text { Weighted Average(Defini- } \\
\quad \text { tion 1) }\end{array}$} & \multirow[t]{2}{*}{ Total1-6 } & intelectuals & 6,00 & 8,00 & 12,00 & 15,00 & 19,00 & 21,00 & 25,00 \\
\hline & & students & 7,00 & 9,00 & 11,50 & 15,00 & 18,00 & 21,00 & 24,00 \\
\hline & \multirow[t]{2}{*}{ Total 7-12 } & intelectuals & 15,00 & 16,00 & 18,00 & 20,00 & 21,00 & 24,00 & 24,00 \\
\hline & & students & 14,00 & 17,00 & 19,00 & 20,00 & 21,00 & 22,00 & 24,50 \\
\hline & \multirow[t]{2}{*}{ Total 13-15 } & intelectuals & 8,50 & 9,00 & 9,00 & 10,00 & 12,00 & 13,00 & 13,00 \\
\hline & & students & 5,50 & 7,00 & 8,50 & 10,00 & 10,00 & 12,00 & 12,50 \\
\hline & \multirow[t]{2}{*}{ Total 16-22 } & intelectuals & 15,00 & 15,00 & 16,50 & 21,00 & 24,50 & 27,00 & 29,00 \\
\hline & & students & 15,00 & 16,00 & 20,00 & 22,00 & 24,50 & 27,00 & 28,00 \\
\hline & \multirow[t]{2}{*}{ Total 23-30 } & intelectuals & 23,00 & 27,00 & 28,50 & 30,00 & 33,00 & 34,00 & 35,00 \\
\hline & & students & 25,50 & 27,00 & 28,00 & 30,00 & 33,00 & 34,00 & 36,50 \\
\hline
\end{tabular}

\begin{tabular}{|l|}
\hline 95 \\
\hline 25,00 \\
\hline 24,00 \\
\hline 26,00 \\
\hline 24,50 \\
\hline 13,00 \\
\hline 12,50 \\
\hline 29,00 \\
\hline 28,00 \\
\hline 35,00 \\
\hline 36,50 \\
\hline
\end{tabular}

Ranks

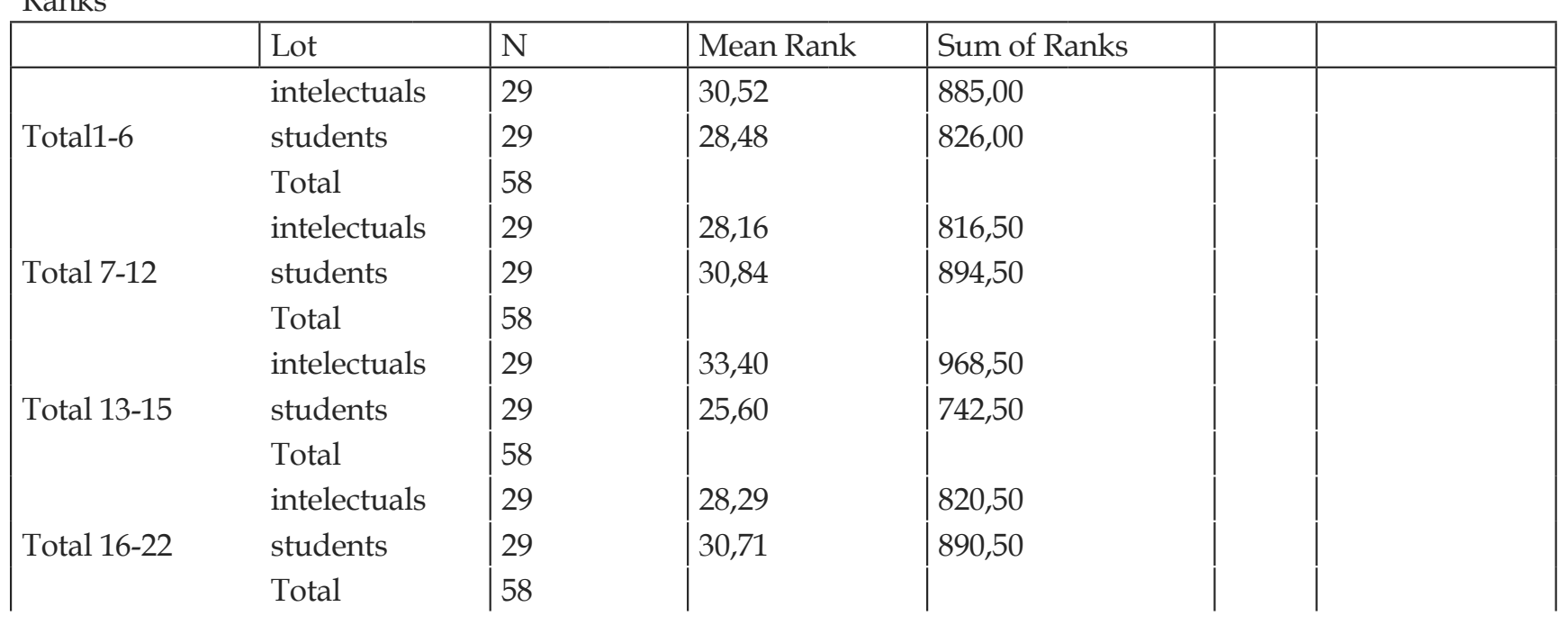




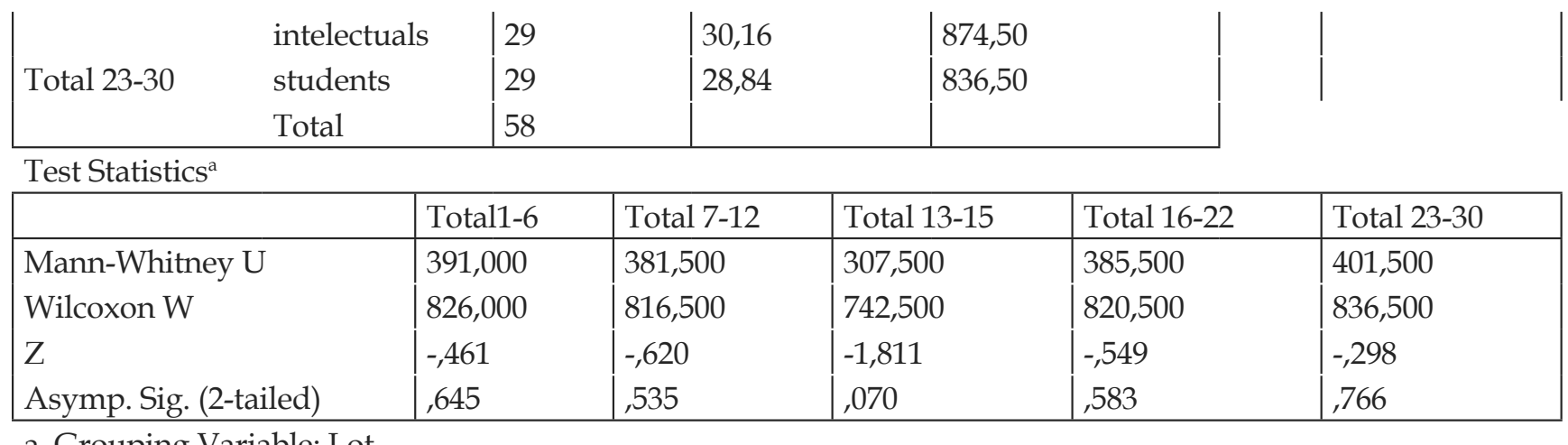

a. Grouping Variable: Lot

\begin{tabular}{|c|c|c|c|c|c|c|c|c|c|}
\hline \multicolumn{10}{|l|}{ Percentiles } \\
\hline & & \multirow[t]{2}{*}{ Lot } & \multicolumn{7}{|c|}{ Percentiles } \\
\hline & & & 5 & 10 & 25 & 50 & 75 & 90 & 95 \\
\hline \multirow{10}{*}{$\begin{array}{l}\text { Weighted Average- } \\
\text { (Definition 1) }\end{array}$} & \multirow[t]{2}{*}{ Total1-6 } & intelectuals & 6,00 & 8,00 & 12,00 & 15,00 & 19,00 & 21,00 & 25,0 \\
\hline & & pupils & 6,00 & 6,90 & 10,25 & 14,50 & 16,00 & 19,00 & 19,55 \\
\hline & \multirow[t]{2}{*}{ Total 7-12 } & intelectuals & 15,00 & 16,00 & 18,00 & 20,00 & 21,00 & 24,00 & 26,00 \\
\hline & & pupils & 14,00 & 14,00 & 18,00 & 20,00 & 22,00 & 23,10 & 24,00 \\
\hline & \multirow[t]{2}{*}{ Total 13-15 } & intelectuals & 8,50 & 9,00 & 9,00 & 10,00 & 12,00 & 13,00 & 13,00 \\
\hline & & pupils & 5,45 & 6,90 & 8,00 & 9,50 & 10,00 & 11,00 & 11,00 \\
\hline & \multirow[t]{2}{*}{ Total 16-22 } & intelectuals & 15,00 & 15,00 & 16,50 & 21,00 & 24,50 & 27,00 & 29,00 \\
\hline & & pupils & 13,00 & 13,90 & 19,00 & 21,50 & 23,75 & 25,00 & 26,10 \\
\hline & \multirow[t]{2}{*}{ Total 23-30 } & intelectuals & 23,00 & 27,00 & 28,50 & 30,00 & 33,00 & 34,00 & 35,00 \\
\hline & & pupils & 22,35 & 24,90 & 29,00 & 30,50 & 33,75 & 36,00 & 37,10 \\
\hline
\end{tabular}

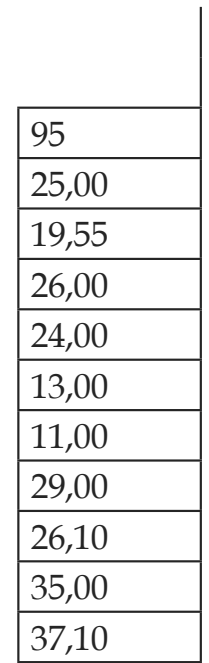


Ranks

\begin{tabular}{|c|c|c|c|c|c|c|c|c|c|}
\hline & Lot & \multicolumn{2}{|c|}{$\mathrm{N}$} & \multicolumn{2}{|c|}{ Mean Rank } & \multicolumn{2}{|c|}{ Sum of Ranks } & & \\
\hline \multirow{4}{*}{ Total1-6 } & intelectuals & & 29 & & 32,21 & & 934,00 & & \\
\hline & pupils & & 28 & & 25,68 & & 719,00 & & \\
\hline & Total & & 57 & & & & & & \\
\hline & intelectuals & & 29 & & 28,14 & & 816,00 & & \\
\hline \multirow[t]{3}{*}{ Total 7-12 } & pupils & & 28 & & 29,89 & & 837,00 & & \\
\hline & Total & & 57 & & & & & & \\
\hline & intelectuals & & 29 & & 34,53 & & 1001,50 & & \\
\hline \multirow[t]{3}{*}{ Total 13-15 } & pupils & & 28 & & 23,27 & & 651,50 & & \\
\hline & Total & & 57 & & & & & & \\
\hline & intelectuals & & 29 & & 29,03 & & 842,00 & & \\
\hline \multirow[t]{3}{*}{ Total 16-22 } & pupils & & 28 & & 28,96 & & 811,00 & & \\
\hline & Total & & 57 & & & & & & \\
\hline & intelectuals & & 29 & & 27,83 & & 807,00 & & \\
\hline \multirow[t]{2}{*}{ Total 23-30 } & pupils & & 28 & & 30,21 & & 846,00 & & \\
\hline & Total & & 57 & & & & & & \\
\hline \multicolumn{10}{|c|}{ Test Statistics ${ }^{\mathrm{a}}$} \\
\hline & & Total1-6 & & al 7-12 & Tota & $13-15$ & Total 16 & -22 & Total 23-30 \\
\hline \multicolumn{2}{|c|}{ Mann-Whitney U } & 313,000 & & 381,000 & & 245,500 & & 5,000 & 372,000 \\
\hline \multirow{2}{*}{\multicolumn{2}{|c|}{$\begin{array}{l}\text { Wilcoxon W } \\
\text { Z }\end{array}$}} & 719,000 & & 816,000 & & 651,500 & & 1,000 & 807,000 \\
\hline & & $-1,489$ & &,- 403 & & $-2,652$ & &,- 016 &,- 547 \\
\hline \multicolumn{2}{|c|}{ Asymp. Sig. (2-tailed) } & ,137 & &, 687 & &, 008 & & ,987 & ,585 \\
\hline
\end{tabular}

